\title{
Penanganan Konsultasi Hukum Di Badan Konsultasi Hukum Fakultas Hukum Undip 2018
}

\author{
Nur Adhim \\ Fakultas Hukum, Universitas Diponegoro \\ bkh@live.undip.ac.id
}

\section{A. IDENTITAS :}

$\mathrm{N}$ a m a : Muhsonalia (Ahli Waris)

Alamat : RT 03/ RW 03 Kel. Mangunharjo Kec. Tugu Kota semarang

Telp : :082226246635

Topik Kasus : Masalah Tanah.

\section{B. FAKTA - FAKTA :}

Bahwa telah ada Putusan PN Semarang Nomor 70/Pdt.G/2015/PN.Smg tg1 9 September 2015 yang amarnya Menolak Gugatan para Penggugat untuk seluruhnya (Mushonalia adalah adalah Penggugat 2).Putusan tersebut dalam Tingkat banding dikuatkan oleh Pengadilan Tinggi Semarang Nomor 67/Pdt/2016/PT.Smg tertanggal 10 Maret 2016. Kemudian dalam Tingkat Kasasi perkara tersebut dinyatakan DITOLAK dalam perkara Nomor 2928 K/PDT/2016 tertanggal 13 Desember 2016

C. ANALISIS

Bahwa kasus ini adalah kasus Penjaminan Tanah dg HAK TANGGUNGAN di Bank PT Bank MNC Internasional Tbk (Dahulu bank ICB Bumiputera Tbk Cabang Semarang). Bahwa tanah tersebut milik dan sertipikat an Ibu Alfiyah binti Sarno sendiri (Ibu dari para Penggugat), dan tidak bisa dibuktikan bahwa tanah itu tanah warisan dari alm Sakdun (Suami ibu Alfiyah/Ayah Para Penggugat). Karena menunggak dan setelah diberi peringatan 3 kali akhirnya tanah jaminan ini di lelang via kantor lelang (KPKNL) dan sudah dibeli pihak ke 3 dan sudah di balik nama. Sehingga

D. PENDAPAT HUKUM KONSULTAN 
Bahwa tanah tersebut bukan tanah warisan (tidak dapat dibuktikabn sbg warisan dalam persidangan di pengadilan) tapi sepenuhnya an Alfiyah binti Sarno (Ibu para penggugat/tergugat) sebagai Pemberi Hak Tanggungan yang dijaminkan di bank dengan dibebani Hak Tanggungan, sedangkan Debiturnya adalah salah satu anak yaitu Fatoni (Tergugat ) yang akhirnya macet dan dijual lelang. Dalam Hukum khususnya UU Hak Tanggungan Nomor 4 Tahun 1996 bahwa boleh saja seorang Debitor meminjam uang di bank dengan jaminan Tanah milik orang lain, asal pemilik tanah tersebut ikut bertanda tangan serta dalam APHT (Akta Pemberian Hak Tanggungan) sebagai Pemberi Hak Tanggungan. Dalam kasus ini Debitornya anaknya (Fatoni) dan tanahnya milik ibunya (Alfiyah) yang beliau pemilik tanah juga bertanda tangan dalam APHT sehingga penjaminan ini sah menurut hukum dan dijual lelang didepan umum, maka jual belinya juga sah menurut hukum.

\section{E. TINDAK LANJUT}

Upaya hukum sudah dilakukan semuanya dari Banding dan Kasasi, kalaupun mau Upaya banding luar biasa (PK) tidak ada alasan untuk itu. Oleh karena itu secara hukum perkara/kasus ini sudah selesai dan harus diterima sebagaimana adanya.

Semarang, 26 Maret 2018

Mengetahui :

Ketua BKH FH UNDIP

Konsultan BKH FH

UNDIP

(ERY AGUS PRIYONO, SH, M.SI)

( NUR ADHIM,

$\mathrm{SH}, \mathrm{MH}$ ) 